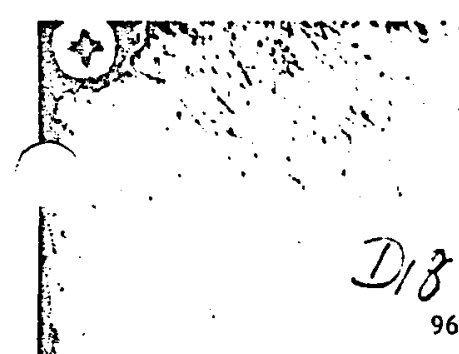

\title{
กิ $85-20468$
}

VIF-RADAR OBSERVATIOHS IN THE STRATOSPHERE AHD MESOSFAERE DURING A STRATOSFHERIC WARMINC

R. Ruster, P. Crechousky and G. Schmidt

Max Planck Inetitute of Aeronomy

3411 Rat lenburg-Lindau, FRG

R. Labitzke

Heteorologica: Institute

Free University

1000 Berlin 33. FRG

The SOUSY-VHF-Radar (lat. $51^{\circ} \mathrm{H}, 10 \mathrm{~g}, 10^{\circ} \mathrm{E}$ ) vas used to carry out measurements during minor and a major atratospheric varuing in February and March altitude of achoes have beco received from the stratosphere up to on the cesosphe of about $30 \mathrm{~km}$ continuously during day and night, wheress echoes fron different height dieensions velocity vecthe altitude range from $60 \mathrm{~km}$ to $90 \mathrm{~kg}$. The threethree different an becn derived fron Doppler geasurenents nade in particular the results on directions uith a height resolution of $1.5 \mathrm{~km}$. Io the zons lind results obtained during disturbed conditions show the change of analysis reveal component.
coliurnal and n veaker cemidiurnal tide of the zonal vind This paper has been publiohed in full in: J. Atmcs. Terr. Phys., $45,161$.
$(1983)$. 